In most rodents the naked rhinarium is compara. tively restricted and frequently partially or completely overshadowed by folds from neighbouring hair-clad parts of the muzzle. But the internarial septum and the immediate margins of the nares are generally free from hairs or at least glabrous. At the medial angle of the narial opening is a more or less raised area of rounded or oval outline. Relatively little raised in Lepus and Oryctolagus, it becomes more prominent in Sciuromorpha and Myomorpha, encroaching upon the internarial region sometimes to the extent of being separated from its fellow merely by a median vertical sulcus.

The surface of the above-mentioned elevation is variously sculptured in different species. In Sciurus it is merely papillated. In the Lagomorpha the anterior two thirds is finely papillated, the papillæ being arranged in longitudinal rows, but on the posterior third the papillæ appear to have fused to form a series (five to six) of longitudinal ridges closely simulating the papillary ridges of the Primate cheiridium. In the Myomorpha the whole surface is definitely ridged in the same manner as the Primate hand, the pattern being generally a simple one. In Rattus norvegicus, for example, there is an arrangement in arches, with their summits directed medially. In at least one genus, Lophiomys, a suspicion of a triradius was observed. It remains to be seen what degree of individual variation, if any, occurs in the pattern. The nature of the nerve endings in this specialized apparatus will also require investigation.

Details are being published elsewhere.

Anatomy Department,

$$
\text { W. C. CSMAN HIIL }
$$

University of Edinburgh.

\section{Chromosome Number of Cardamine pratensis}

THE chromosome number of Cardamine pratensis $\mathrm{L}$. has been investigated by a number of cytologists and, as is shown in the table, several numbers have been reported.

\begin{tabular}{|c|c|c|}
\hline Author & Locality of specimens & $\begin{array}{c}\text { Somatic } \\
\text { chromosome }\end{array}$ \\
\hline $\begin{array}{l}\text { Manton }^{1} \\
\text { Manton }^{1} \\
\text { Lawrence }^{2} \\
\text { Flovik }^{3}\end{array}$ & $\begin{array}{l}\text { Cambridge } \\
\text { Double varieties from botanic gardens } \\
\text { Merton, London } \\
\text { Spitsbergen }\end{array}$ & $\begin{array}{l}\text { number } \\
\text { c. } 32 \\
\text { c. } 64 \\
30 \\
64\end{array}$ \\
\hline Lövkvist4 & Southern Sweden & $\begin{array}{l}30,56, \quad 60, \\
64,68,72 \\
\text { and } 76\end{array}$ \\
\hline
\end{tabular}

The work of Lövkvist is of considerable interest in that he found a relationship between chromosome number and dampness of habitat; plants with 30 chromosomes being found in the higher parts of meadows, plants with 56-68 chromosomes being found in the lower parts and plants with 72 and 76 chromosomes near or in the water. This work also suggested that chromosome counts of wild British plants might be interesting.

Plants from three localities near Cambridge (Grantchester Meadows, Milton and Wicken Fen) and one plant from High Lane, Cheshire, have now been examined. All these have been found, from second metaphase plates of pollen mother cells (Feulgen stained squashes), to have a chromosome number of $n=28$ (that is, a somatic chromosome number of 56). All these plants came from rather wet situations, and it also appears that Lawrence's material from the John Innes Horticultural Institution's garden came from a rather dry place. There thus seems to be some confirmation of Lövkvist's findings.

The systematic position is somewhat obscure and Lövkvist goes no further than suggesting that "Cardamine pratensis and $C$. dentata are probably the extremes in a series of types having more or fewer traits from the one or other of the two species". Lövkvist also states that he only found meiotic irregularities in forms having 30 chromosomes. In my material, however, two univalent chromosomes were common in the 56 chromosome plants.

My thanks are due to J. P. Cooper for the High Lane plant and to V. Chapman for making the cytological preparations.

\section{Plant Breeding Institute, \\ School of Agriculture, \\ Cambridge. \\ Nov. 5.}

${ }^{1}$ Manton, I., Ann. Bot., 46, 509 (1932).

Lawrence, W. J. C., Genetica, 13, 183 (1932).

${ }^{3}$ Flovik, K., Hereditas, 26, 430 (1940).

- Lövkvist, B., Hereditas, 33, 421 (1947).

\section{H. W. HOW ARD}

\section{Chronometric Observations of the Song of Fringilla coelebs Linn.}

DURING the 1946 breeding season of the common chaffinch (Fringilla colebs L.), 5,468 observations were obtained of the song interval, that is, the time taken by the cock bird to utter his characteristic sequence of notes ${ }^{1}$. A split-second hand chronometer was used to record the duration of the interval to the nearest tenth of one second, and a correction was applied to eliminate the personal equation of the observer. Corrected times are considered accurate to \pm 0.1 sec. No particular care was taken to ensure that successive records were obtained from the same birds, since it was desired to examine a typically representative cross-section of the local chaffinch population. Recording was made under a variety of weather conditions to assess the possible influence of certain meteorological factors on the duration and frequency distribution of the interval value defined previously.

The chief results of analysing the complete data may be briefly summarized as follows:

(i) The mean value of the song interval, based on 10-day averages of all the observations, is found to be $1.9 \pm 0.1 \mathrm{sec}$. The 10 -day average values exhibit a well-marked seasonal fluctuation yielding a single, flat maximum of amplitude $0.6 \mathrm{sec}$. This trend is shown by the data of Table 1 .

TABLE 1. SEasonal MaRch OF aVERAGE SONG INTERVAL Days from onset of

$\begin{array}{lllllllll}\text { singing } & 5 & 15 & 35 & 55 & 75 & 105 & 125 & 135\end{array}$

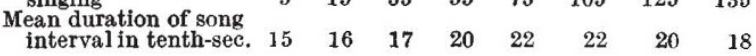

By interpolation it is found that the maximum value of the mean song interval is attained by about the ninetieth day after the onset of singing. Both previous to, and subsequent to, this date the interval is shorter, the rate of variation being most rapid towards the end of the season (the marked rise observed between the thirty-fifth and fifty-fifth days most probably resulted from an abnormally low air temperature during the preceding twenty days).

(ii) Of the four meteorological factors studied in conjunction with the chronometric records, relative humidity affects the song interval most markedly. 